Teknik, 37 (1), 2016, 32-40

\title{
Modifikasi Pati Sukun (Artocarpus Altilis) dengan Teknik Oksidasi Menggunakan Hidrogen Peroksida Tanpa Katalis
}

\author{
Catarina Sri Budiyati*), Andri Cahyo Kumoro, Ratnawati Ratnawati, Diah Susetyo Retnowati \\ Departemen Teknik Kimia, Fakultas Teknik, Universitas Diponegoro, \\ Jl. Prof. Soedarto, SH, Kampus Undip Tembalang, Semarang, Indonesia 50275
}

\begin{abstract}
Abstrak
Salah satu sumber bahan pangan lokal yang belum banyak dimanfaatkan adalah buah sukun (Artocarpus Artilis) yang cukup banyak terdapat di Indonesia. Akan tetapi, pemanfaatan buah sukun terkendala pada kurangnya daya simpan buah segar. Oleh karena itu, perlu dilakukan upaya untuk meningkatkan pemanfaatan buah sukun dengan mengolahnya menjadi produk yang lebih luwes dengan daya simpan yang lebih baik, yaitu menjadi pati sukun. Sifat-sifat pati sukun perlu diperbaiki agar dapat digunakan sebagai pengganti tepung terigu. Tujuan dari penelitian ini adalah untuk memodifikasi pati sukun dengan cara oksidasi menggunakan larutan hidrogen peroksida. Dalam penelitian ini dikaji pengaruh konsistensi luluhan, konsentrasi hidrogen peroksida, waktu, dan suhu terhadap karakteristik fisikokimia pati sukun teroksidasi yang dihasilkan dan ditentukan kondisi optimalnya. Hasil penelitian menunjukkan bahwa semua variable yang dikaji tersebut mempengaruhi reaksi oksidasi pati sukun. Oksidasi pada konsistensi luluhan 20\%, konsentrasi hidrogen peroksida $2 \%$ dan suhu $50{ }^{\circ} \mathrm{C}$ mampu menghasilkan nilai swelling power dan water solubility yang terbaik. Reaksi oksidasi tidak mengubah struktur dan morfologi pati sukun termodifikasi secara signifikan.
\end{abstract}

Kata kunci: hidrogen peroksida; oksidasi; pati; sukun

\begin{abstract}
[Title: Modification of Breadfruit (Artocarpus altilis) starch through non-catalytic hydrogen peroxide oxidation] One of local source of food that has not been intensively explored is breadfruit (Artocarpus Artilis). However, the utilization of breadfruit is limited by the poor storage properties of the fresh fruit. Therefore, efforts should be made to improve the utilization of breadfruit to process it into more flexible products with better storability, suach as breadfruit starch. Breadfruit starch properties need to be improved so that it can be used to substitute wheat flour. The aim of this study was to modify the breadfruit starch by oxidation using hydrogen peroxide solution. This work studied examined the influence of consistency of starch slurry, hydrogen peroxide concentration, time, and temperature on the physicochemical properties of the oxidized breadfruit starch. The optimal conditions were also determined. The results showed that all of these variables affected the oxidation of starch breadfruit. The oxidation on starch slurry with consistency $20 \%$, the concentration of hydrogen peroxide of $2 \%$, and temperature of $50^{\circ} \mathrm{C}$ produced modified starch with best swelling power and water solubility. The oxidation did not significantly change the structure and morphology of the modified starch..
\end{abstract}

Keywords: breadfruit; hydrogen peroxide; oxidation; starch

\section{Pendahuluan}

Sukun (Artocarpus astilis) (Gambar 1) merupakan suatu spesies tanaman yang tersebar di Polinesia, Pasifik dan Asia Tenggara, termasuk

\footnotetext{
${ }^{*}$ Penulis Korespondensi.

E-mail: budiyati@undip.ac.id
}

Indonesia. Buah sukun biasanya dipanen dua kali setahun, yaitu pada bulan Januari-Februari dan bulan Agustus-September. Buah sukun masak tidak bisa disimpan terlalu lama karena cepat membusuk (Adebowale, 2005). Oleh karena itu, perlu dilakukan upaya untuk meningkatkan pemanfaatan buah sukun dengan mengolahnya menjadi produk-produk yang lebih 
Teknik, 37 (1), 2016, 33

beragam, ekonomis dan daya simpan yang lebih baik, seperti pengolahan menjadi tepung dan pati sukun.

Sifat fungsional pati buah sukun sebagai komposit tepung sudah dikaji oleh Esuoso dan Bamiro (1995). Walaupun mempunyai kelarutan dalam air (water solubility/WS) yang cukup baik $(55,27 \mathrm{~g} / 100 \mathrm{~g})$, namun pati buah sukun mempunyai daya kembang (swelling power/SP) yang rendah $(1,55 \mathrm{~g} / \mathrm{g})$, sehingga tidak dapat dipergunakan sebagai bahan dasar roti (Adebowale, 2005). Pemanfaatan pati dan tepung untuk berbagai keperluan pada dasarnya masih terkendala oleh beberapa kelemahannya, seperti kerentanan terhadap panas, kekentalan yang terlalu tinggi, rendahnya nilai tahanan terhadap geseran, dan tingginya kecenderungan untuk mengalami retrogradasi dan sineresis. Oleh karena itu, pati dan tepung perlu dimodifikasi, baik secara kimia, fisika, enziymatik maupun biologis.

Setiap teknik modifikasi pati dan tepung akan menghasilkan produk polimer dengan sifat yang khas. Pati tersusun atas amilose yang berupa polimer berantai lurus dari satuan monomer -(1-4) glukosa, dan amilopektin yang berupa polimer berantai cabang dari satuan monomer -(1-4) glukosa dengan percabangan berkala pada posisi -(1-6) (Serrero dkk., 2010). Gugusgugus hidroksil pada pati sangat mudah dipaparkan terhadap suatu reaksi kimia, diantaranya melalui mekanisme oksidasi, esterifikasi, eterifikasi, dan lainlain (Zdanowicz dkk., 2010). Pada dasarnya, modifikasi pati ditujukan untuk memotong ikatan antara molekulmolekul -(1-4) glukosa, mengganti gugus hidroksil atau menambah gugus fungsional lainnya ke dalam molekul pati. Pada reaksi oksidasi, maka gugus-gugus hidroksil pada posisi C-2, C-3, dan C-6, diubah menjadi gugus karbonil dan/atau karboksil (Kurakake dkk., 2009). Dengan demikian, jumlah gugus karboksil dan karbonil yang terdapat pada pati teroksidasi menunjukkan tinggi rendahnya nilai derajat oksidasi (DO).

Pati dengan nilai DO antara 0,01-0,2 sangat diperlukan dalam industri makanan dan obat-obatan, sedangkan pati dengan DO 0,2-3,0 diperlukan dalam industri plastik, kertas, tekstil, cat dan lain-lain (Tomasik, 2004). Oksidasi secara konvensional biasanya menggunakan oksidator anorganik, seperti hipokhlorit, permanganat, dikhromat, nitrogen oksida (Silva dkk., 2008) dan persulfat (Zhang dkk., 2007) untuk memasukkan gugus karboksil (Kuakpetoon dan Wang, 2008) atau periodat untuk mendapatkan ikatan C-C dan gugus aldehid (Varma dkk., 1997). Namun, oksidatoroksidator tersebut cukup mahal, beracun dan menghasilkan banyak limbah, seperti senyawa terhalogenasi, logam berat dan garam nitrat dan nitrit. Oleh karena itu, ditinjau dari sudut pandang ekonomi dan kelestarian lingkungan, maka oksidasi pati dengan oksidator dan katalis yang murah dan ramah lingkungan sangat diperlukan. Beberapa percobaan oksidasi pati dengan hidrogren peroksida $\left(\mathrm{H}_{2} \mathrm{O}_{2}\right)$ telah banyak dilakukan karena oksidator ini ramah lingkungan dan dalam batas tertentu diperbolehkan untuk pengolahan makanan.

Penelitian terdahulu tentang oksidasi pati gadung yang dapat meningkatkan nilai baking expansion dan kelarutan adalah modifikasi dengan teknik oksidasi (Kumoro dkk., 2012). Penelitian lain yaitu oksidasi tepung talas dengan $\mathrm{H}_{2} \mathrm{O}_{2}$ dan katalis $\mathrm{CuSO}_{4}$ dapat menaikkan nilai daya kembang dan kelarutan dalam air, tetapi ada residu logam Tembaga dari katalis yang tertinggal di dalam tepung. Hal ini mengakibatkan terjadinya perubahan warna pada tepung talas. Bila oksidasi ini dilakukan tanpa katalis akan dihasilkan tepung talas dengan $\mathrm{SP}=7,2 \mathrm{~g} / \mathrm{g}$ dan $\mathrm{WS}=6,93 \%$ (Budiyati dan Ariyanti, 2014), yang setara dengan tepung terigu Amerika yang mempunyai nilai $\mathrm{SP}=6,9-$ $7,9 \mathrm{~g} / \mathrm{g}$; dan WS $=6,3-7,3 \%$ (Chung dkk., 2010). Swelling power untuk pati gandum adalah $6.1 \%$ (Blazek and Copeland, 2008). Oleh karena itu, penelitian ini bertujuan untuk mengkaji oksidasi pati buah sukun dengan larutan hidrogen peroksida tanpa menggunakan katalis. Agar menghasilkan pati sukun teroksidasi yang berkualitas, maka pengaruh konsistensi luluhan, konsentrasi hidrogen peroksida, waktu, dan suhu terhadap karakteristik fisikokimia pati sukun teroksidasi yang dihasilkan akan dikaji dan ditentukan kondisi optimalnya.

\section{Bahan dan Metode \\ 2.1. Bahan}

Bahan baku yang digunakan dalam penelitian ini adalah buah sukun (Artocarpus astilis), air suling, hidrogen peroksida. Pati sukun dibuat dari buah sukun yang dibeli dari pekebun buah sukun di Semarang. Air suling diperoleh dari Unit Reverse Osmosis (RO) yang tersedia di Jurusan Teknik Kimia, Fakultas Teknik, Universitas Diponegoro. Sementara itu, $\mathrm{H}_{2} \mathrm{O}_{2}$ dalam bentuk larutan (30\%, Sigma Aldrich) diperoleh dari distributor resmi Sigma-Aldrich di Semarang.

\subsection{Modifikasi Pati Sukun dengan Teknik Oksidasi}

Pati sukun dioksidasi dengan 2\% larutan oksidator hidrogen peroksida $\left(\mathrm{H}_{2} \mathrm{O}_{2}\right)$ tanpa katalis menurut metode yang dilakukan oleh Parovuori dkk. (1995). Seratus gram pati didispersikan di dalam air suling untuk memperoleh suspensi dengan berbagai kadar pati sukun yang dikaji. Selanjutnya, oksidasi dilakukan pada suhu $30^{\circ} \mathrm{C}$ dengan pengadukan secara terus-menerus. Larutan oksidator hidrogen peroksida ditambahkan tetes demi tetes hingga konsentrasinya dalam suspensi mencapai nilai yang diinginkan. Proses oksidasi dilangsungkan selama 120 menit dengan pengambilan sampel setiap 30 menit untuk dianalisis kandungan gugus karbonil, karboksil, dan komposisi kimianya serta profil struktur patinya. 
Sampel pati sukun teroksidasi yang diperoleh selanjutnya dicuci dengan air suling sebanyak 4 kali, disaring, dikeringkan pada suhu $50^{\circ} \mathrm{C}$ selama 48 jam dan digiling sampai kehalusan 100 mesh. Setiap sampel yang diperoleh kemudian dibungkus dengan plastik kedap udara dan disimpan pada suhu $28 \pm 2{ }^{\circ} \mathrm{C}$ untuk keperluan percobaan selanjutnya dan analisis. Secara visual, keberhasilan reaksi oksidasi dianalisis berdasarkan hasil scanning electron microscopy (SEM) untuk mengetahui ukuran dan bentuk pati sukun teroksidasi yang diperoleh. Analisis kandungan gizi dan keamanan pati sukun termodifikasi tersebut juga dilakukan sebelum dikonsumsi atau diproses lebih lanjut.

Variabel yang dikaji adalah konsentrasi pati $(10 \%, 20 \%$, dan 30\%), waktu reaksi $(30,60,90$, dan 120 menit), konsentrasi oksidator $\mathrm{H}_{2} \mathrm{O}_{2}(1 \%, 2 \%$, dan $3 \%)$ serta suhu oksidasi $\left(30,40\right.$, dan $\left.50^{\circ} \mathrm{C}\right)$.

\subsection{Analisis Sifat Fisiko-kimia Pati Sukun Teroksidasi}

Pati termodifikasi dianalisis proksimat dan struktur patinya dengan pemindaian dengan Mikroskop Elektron (Scanning Electron Microscopy/SEM). Sifatsifat fungsional pati sukun asli dan teroksidasi yang berkaitan dengan citarasa, pencernaan dan pengolahan bahan pangan, yaitu water solubility (WS) ditentukan dengan metode yang dikembangkan oleh Kainuma dkk. (1967) dan swelling power (SP) ditentukan menurut metode Leach dkk. (1959).

\section{Hasil dan Pembahasan}

\subsection{Analisis Proksimat Bahan Baku}

Hasil analisis proksimat pati buah sukun yang meliputi kadar air, abu, protein, lemak dan karbohidrat disajikan pada Tabel 1. Pada Tabel 1 nampak bahwa kadar air pati sukun yang digunakan dalam penelitian ini masih jauh lebih tinggi jika dibandingkan dengan kadar air menurut SNI. Kadar air yang tinggi dapat menyebabkan pati sukun mudah rusak karena rentan terhadap serangan jamur dan mikroflora lainnya. Kadar karbohidrat, abu dan lemak pati sukun hampir setara dengan tepung terigu komersial yang dilaporkan oleh Gunathilake dkk. (2008), sedangkan kadar proteinnya hanya $1 / 6$ dari kadar protein tepung terigu tersebut.
Jika analisis proksimat pati sukun pada penelitian ini dibandingkan dengan pati sukun yang dilaporkan oleh Loos dkk. (1981), maka nilai kadar lemak dan kadar abu keduanya hampir setara. Tetapi kadar air pada pati sukun yang digunakan dalam penelitian ini jauh lebih tinggi dan menandakan rendahnya daya simpannya. Walaupun kadar karbohidratnya jauh lebih rendah, namun kadar protein pati sukun pada penelitian ini justru jauh lebih tinggi daripada pati sukun dari Puorto Rico yang diteliti oleh Loos dkk. (1981).

\subsection{Pengaruh Konsistensi Luluhan terhadap Swelling Power dan Water Solubility Pati Sukun}

Proses oksidasi pati mengunakan oksidator larutan $\mathrm{H}_{2} \mathrm{O}_{2}$ diawali dengan terbentuknya radikal hidroksil $\left(\mathrm{OH}^{*}\right)$ dari hidrogen peroksida. Radikal ini berperan dalam memotong ikatan rantai molekul amilosa menjadi rantai yang lebih pendek. Hasil kajian mengenai pengaruh konsistensi luluhan terhadap nilai swelling power dan water solubility masing-masing dapat dilihat pada Gambar 1 dan 2.

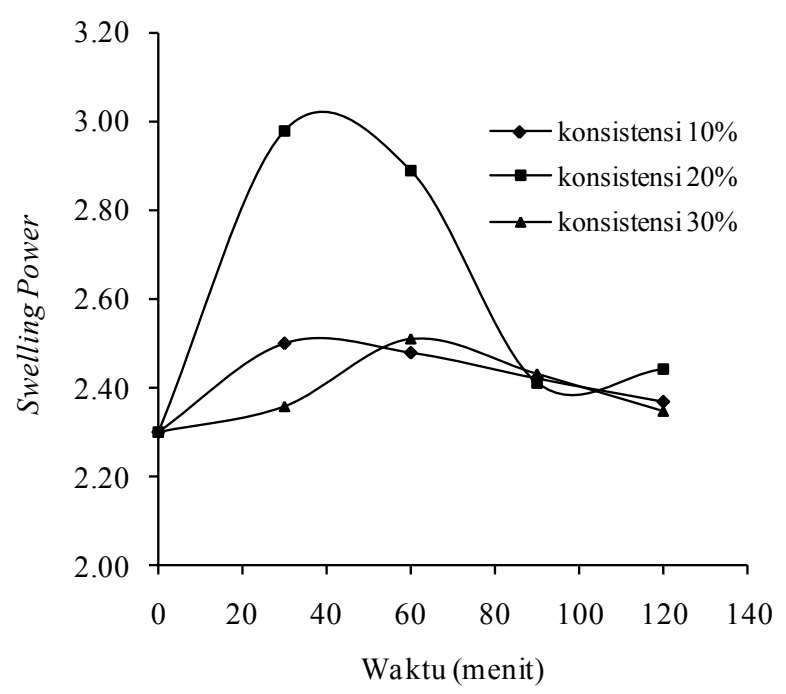

Gambar 1. Pengaruh konsistensi luluhan terhadap swelling power pati sukun termodifikasi pada konsentrasi $\mathrm{H}_{2} \mathrm{O}_{2} 2 \%$, suhu $30^{\circ} \mathrm{C}$, dan berbagai waktu oksidasi

Tabel 1. Hasil analisis proksimat pati sukun (g/100 g pati)

\begin{tabular}{lcccc}
\hline \multicolumn{1}{c}{ Parameter } & $\begin{array}{c}\text { Pati Sukun } \\
\text { (penelitian ini) }\end{array}$ & $\begin{array}{c}\text { Pati Sukun } \\
\text { (Loos dkk., 1981) }\end{array}$ & SNI Tepung Terigu & $\begin{array}{c}\text { Tepung Terigu } \\
\text { (Gunathilake dkk., 2008) }\end{array}$ \\
\hline Air & 19,99 & 7,90 & Maks. 14.5 & 9,76 \\
Abu & 0,49 & 0,30 & Maks. 7 & 0,51 \\
Protein & 1,60 & 0,40 & & 9,90 \\
Lemak & 0,62 & 0,70 & & 0,87 \\
Karbohidrat & 77,31 & 90,70 & & 78,46 \\
\hline
\end{tabular}


Teknik, 37 (1), 2016, 35

Secara tidak langsung, konsistensi luluhan pati mengindikasikan variasi kandungan amilosa dan amilopektin dalam sistem pati sukun yang dioksidasi pada konsentrasi $\mathrm{H}_{2} \mathrm{O}_{2}$ yang tetap. Akanbi dkk. (2009) melaporkan bahwa kandungan amilosa pada pati sukun adalah $22,52 \%$ dan kandungan amilopektin 77,48\%.

Secara teoritik, komposisi kandungan amilosa dan amilopektin ini akan mempengaruhi sifat fungsional dari pati sukun yaitu nilai swelling power dan water solubility. Sandhu dkk. (2008) melaporkan adanya penurunan kadar amilosa pada pati jagung yang dioksidasi dengan larutan natrium hipokhlorit. Begitu pati dan natrium hipkhlorit dicampur, maka amilosa segera bereaksi dengan natrium hipokhlorit (oksidator), sehingga hanya sedikit sisa natrium hipokhlorit yang bisa bereaksi dengan amilopektin. Struktur amilosa yang linier dan susunan amilopektin yang acak menyebabkan amilosa lebih rentan terhadap degradasi secara oksidasi.

Pada umumnya, nilai swelling power akan menurun setelah pati mengalami oksidasi sebagai akibat dari menurunnya kadar amilosa di dalamnya. Tester dan Morrison (1990) menjelaskan bahwa kenaikan kadar amilopektin akan meningkatkan swelling power dan pasting butir pati, sedangkan amilosa dan lemak menghambat swelling. Namun pada penelitian ini oksidasi ternyata meningkatkan swelling power. Hasil yang sama dengan yang dilaporkan oleh Wang dan Wang (2003) pada oksidasi pati jagung dan Matsuguma dkk. (2009) pada oksidasi pati umbi wortel dari Peru. Hal ini dapat dijelaskan bahwa pada saat awal reaksi oksidasi, amilosa lebih mudah terhidrolisis sehingga terjadi depolimerisasi amilosa dan memicu terjadinya swelling (Gambar 1, waktu reaksi sampai dengan 30 menit). Depolimerisasi molekul amilosa mengakibatkan menurunnya derajat kristalinitas (Lawal, 2004) dan molekul air yang terdapat pada sistem dapat dengan mudah diakses oleh molekul amilopektin sehingga menyebabkan meningkatnya nilai swelling power dari tepung. Wang dan Wang (2003) juga menemukan bahwa jika amilopektin terhidrolisis, maka pati akan kehilangan kemampuannya untuk memegang/menyerap air sehingga swelling powernya menurun (Gambar 1 waktu reaksi $>30$ menit).

Pada konsistensi luluhan yang rendah $(10 \% \mathrm{~b} / \mathrm{b})$, jumlah amilosa yang tersedia untuk bereaksi dengan radikal hidroksil hanya sedikit, sehingga terjadi kelebihan jumlah radikal hidroksil dalam sistem reaksi. Akibatnya terjadi oksidasi terhadap amilosa dan amilopektin dalam jumlah yang cukup berimbang, sehingga nilai swelling powernya tidak banyak berubah jika dibandingkan dengan pati sukun asal. Pada konsistensi luluhan 20\%, ketersediaan amilosa sebanding dengan kebutuhan radikal hidroksil teroritik yang diperlukan untuk reaksi. Akibatnya, reaksi berlangsung sangat cepat dengan mendepolimerisasi molekul amilosa yang merupakan lapisan paling luar dari struktur pati dan memiliki derajat kristalinitas tinggi sehingga meningkatkan swelling power pada awal reaksi (0-30 menit). Namun, kemudian reaksi melambat karena jumlah radikal hidroksil sudah sangat berkurang. Semakin lama waktu oksidasi, maka konsentrasi radikal hirdoksil di dalam sistem reaksi berkurang sehingga reaksi berlangsung lambat, oleh karena itu waktu optimal oksidasi adalah 60 menit (Zhang dkk., 2012). Pada konsistensi luluhan yang tinggi (30\%), jumlah radikal hidroksil yang tersedia tidak sebanding dengan jumlah amilosa yang tersedia. Dengan demikian, reaksi antara radikal hidroksil dengan amilosa masih menyisakan banyak amilosa di dalam butir pati. Secara teknis, penggunaan konsistensi luluhan yang tinggi juga membutuhkan lebih banyak energi untuk mengaduk agar bereaksi dengan baik karena viskositas luluhan juga menjadi lebih tinggi. Oleh karena itu, berdasarkan pada hasil analisis swelling power ini, maka konsentrasi luluhan yang dianggap paling baik adalah $20 \% \mathrm{~b} / \mathrm{b}$.

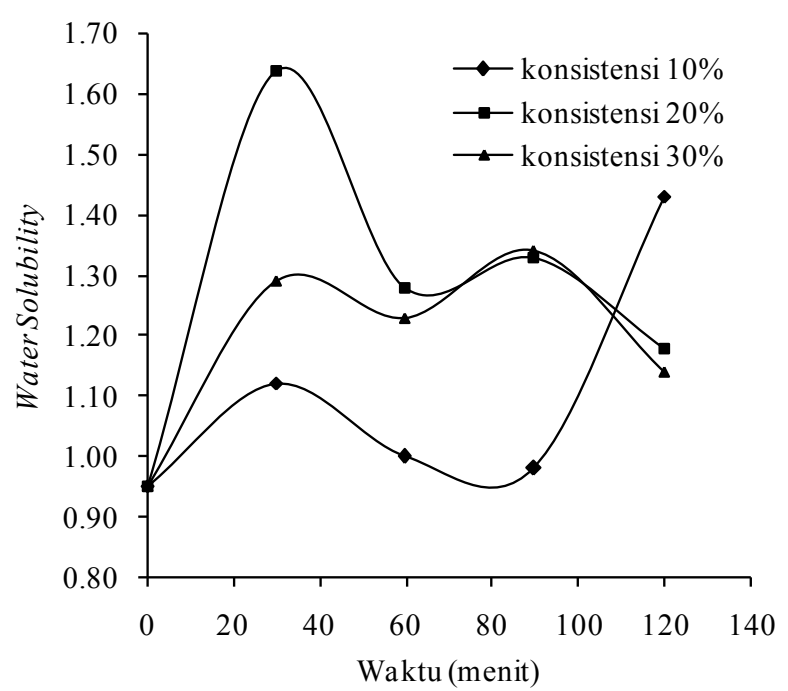

Gambar 2. Pengaruh konsistensi luluhan terhadap water solubility pati sukun termodifikasi pada konsentrasi $\mathrm{H}_{2} \mathrm{O}_{2} 2 \%$, suhu $30^{\circ} \mathrm{C}$ dengan berbagai waktu oksidasi

Loos dkk. (1981) melaporkan bahwa kelarutan pati sukun pada suhu $60^{\circ} \mathrm{C}$ adalah sekitar $0,8 \mathrm{~g} / 100 \mathrm{~g}$, sedangkan pati sukun pada penelitian ini mempunyai nilai kelarutan sekitar $0,9 \mathrm{~g} / 100 \mathrm{~g}$ pada suhu yang sama. Sementara itu, Akanbi dkk. (2009) melaporkan bahwa kelarutan pati sukun dari Ile-efe Nigeria adalah 2,3 g/ 100g. Perbedaan nilai kelarutan ini mungkin disebabkan oleh perbedaan varietas dan komposisi kimia buah sukun yang dikaji. Kelarutan pati sangat tergantung pada nilai kadar amilosa dan kemudahannya untuk keluar dari 
Teknik, 37 (1), 2016, 36

butir pati (Matsuguma dkk., 2009). Gambar 3 menyajikan profil kelarutan pati sukun selama proses oksidasi dengan larutan hidrogen peroksida pada berbagai konsistensi luluhan dan waktu reaksi. Secara umum, kelarutan pati sukun mengalami peningkatan setelah mengalami oksidasi. Hal ini disebabkan oleh terjadinya depolimerisasi dan pelemahan struktur pada butir pati (Hodge \& Osman, 1996). Sementara itu, molekul amilosa yang terdepolimerisasi menjadi molekul rantai pendek mulai terlarut dalam air yang menyebabkan kelarutan tepung dalam air juga meningkat secara signifikan. Hal ini sesuai dengan penelitian yang dilakukan oleh Matsuguma (2009), bahwa kelarutan tepung dalam air dipengaruhi oleh fraksi amilosa yang terlepas dari rantai pati.

\subsection{Pengaruh Konsentrasi $\mathrm{H}_{2} \mathrm{O}_{2}$ terhadap Swelling Power dan Water Solubility Pati Sukun}

Gambar 3 dan 4 menyajikankan nilai swelling power dan water solubility untuk konsistensi luluhan pati $20 \% \mathrm{~b} / \mathrm{b}$, waktu oksidasi 30 menit dan suhu ruangan $\left( \pm 30^{\circ} \mathrm{C}\right)$ pada berbagai konsentrasi $\mathrm{H}_{2} \mathrm{O}_{2}$. Nilai swelling power meningkat seiring dengan meningkatnya konsentrasi $\mathrm{H}_{2} \mathrm{O}_{2}$ yang ditambahkan. Semakin tinggi konsentrasi larutan $\mathrm{H}_{2} \mathrm{O}_{2}$ yang digunakan, berarti lebih banyak radikal hidroksil yang tersedia dalam sistem reaksi. Oleh karena itu, amilosa dan lemak dalam butir pati sukun termodifikasi akan semakin sedikit dan swelling power pati semakin meningkat.

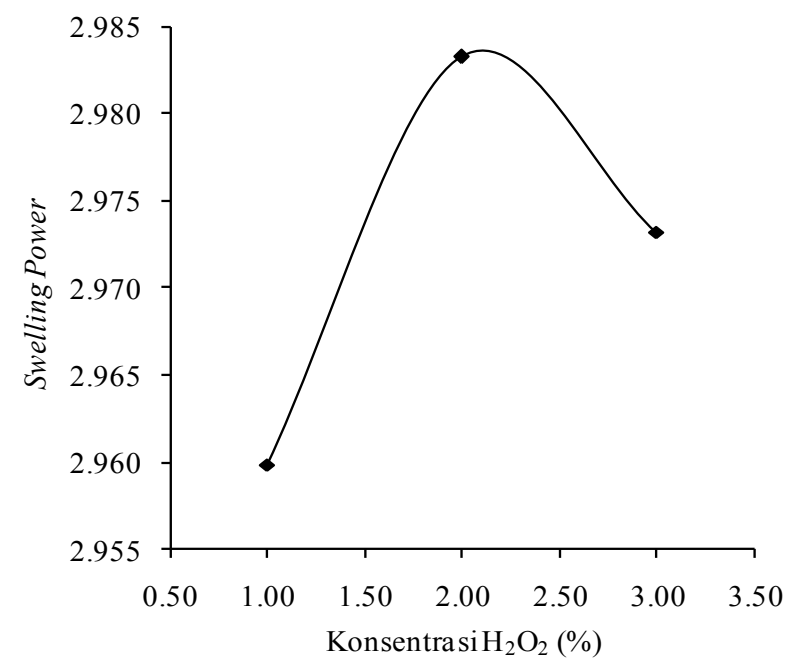

Gambar 3. Pengaruh konsentrasi $\mathrm{H}_{2} \mathrm{O}_{2}$ terhadap swelling power pati sukun termodifikasi dengan konsistensi luluhan $20 \%$, pada suhu $30{ }^{\circ} \mathrm{C}$ dan waktu reaksi 30 menit

Konsentrasi $\mathrm{H}_{2} \mathrm{O}_{2}$ yang lebih tinggi (3\%) justru menurunkan nilai swelling power. Hal ini disebabkan oleh terjadinya oksidasi lanjut yaitu konversi gugus hidroksil dari molekul amilosa dan amilopektin menjadi gugus karbonil kemudian menjadi gugus karboksil. Seperti yang telah dijelaskan sebelumnya, berkurangnya molekul amilopektin pada struktur pati menyebabkan menurunnya molekul pati yang dapat menyerap dan memerangkap molekul air. Hal ini terindikasi dengan rendahnya nilai swelling power (Lawal, 2004).

Semakin tinggi konsentrasi $\mathrm{H}_{2} \mathrm{O}_{2}$ yang digunakan dalam reaksi oksidasi, maka semakin banyak jumlah radikal hidroksil yang terdapat di dalam sistem reaksi. Menurunnya kelarutan pada konsentrasi $\mathrm{H}_{2} \mathrm{O}_{2}$ yang tinggi lebih disebabkan oleh jumlah radikal hidroksil yang berlebihan sehingga radikal-radikal tersebut memusnahkan diri dengan bergabung kembali menjadi $\mathrm{H}_{2} \mathrm{O}_{2}$ sehingga tidak sempat bereaksi dengan pati. Hal tersebut juga dapat disebabkan terjadinya reaksi lanjut (gugus karbonil menjadi gugus karboksil dan hilang melalui proses dekarboksilasi) atau terjadinya oksidasi lanjut yang menyebabkan degradasi pati menjadi fragmen-fragmen dengan rantai karbon yang lebih pendek. Gugus yang terbentuk akibat proses depolimerisasi lanjut juga rentan terhadap terjadinya cross-linking diantara intra molekulnya. Ikatan ini diduga menghambat keluarnya amilosa yang telah terpotong dari rantai pati (terperangkap), sehingga nilai water solubility menjadi lebih rendah (Wang \& Wang, 2003).

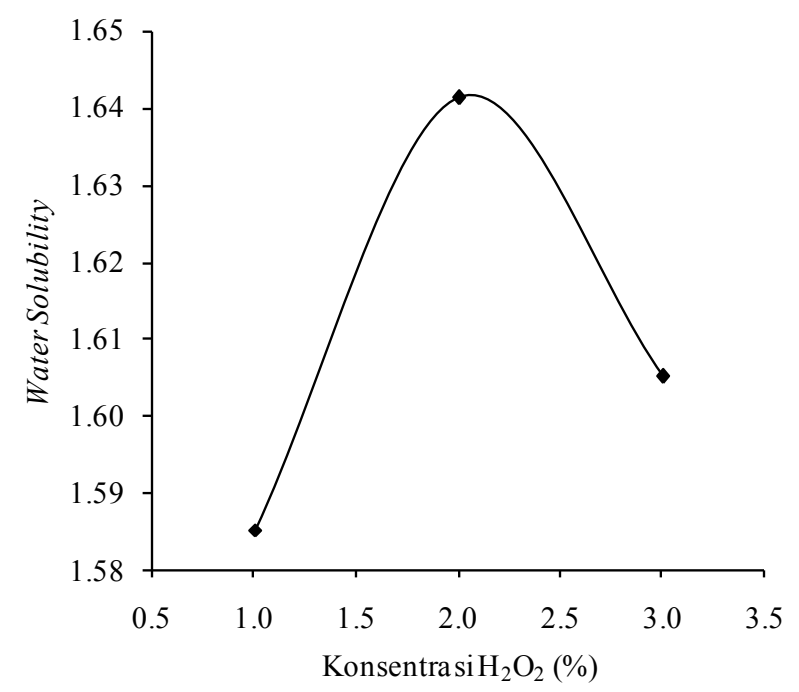

Gambar 4. Pengaruh konsentrasi $\mathrm{H}_{2} \mathrm{O}_{2}$ terhadap water solubility pati sukun termodifikasi dengan konsistensi luluhan $20 \% \mathrm{~b} / \mathrm{b}$ pada suhu $30{ }^{\circ} \mathrm{C}$ dan waktu reaksi 30 menit

\subsection{Pengaruh Suhu terhadap Swelling Power dan Water Solubility Pati Sukun}

Pengaruh suhu terhadap proses oksidasi pati sukun dengan konsistensi luluhan $20 \%$, waktu oksidasi 30 menit dengan konsentrasi $\mathrm{H}_{2} \mathrm{O}_{2} 2 \%$ terhadap swelling power dan water solubility masing-masing dapat dilihat 
Teknik, 37 (1), 2016, 37

pada Gambar 5 dan 6. Suhu reaksi oksidasi dipilih pada $30{ }^{\circ} \mathrm{C}, 40{ }^{\circ} \mathrm{C}$ dan $50{ }^{\circ} \mathrm{C}$. Oksidasi pati sukun tidak dapat dilakukan pada suhu lebih tinggi karena pada suhu $67^{\circ} \mathrm{C}$ pati sukun mulai mengalami gelatinisasi. Selain itu, pada suhu $55^{\circ} \mathrm{C}$ atau lebih tinggi hidrogen peroksida mudah terdekomposisi dan menurunkan nilai derajat oksidasinya (DO). Menurut Tolvanen dkk. (2013), laju dekomposisi $\mathrm{H}_{2} \mathrm{O}_{2}$ pada $52^{\circ} \mathrm{C}$ tanpa katalis dengan atau tanpa adanya pati adalah $0.01-0,0215 \mathrm{~mol} / \mathrm{L} / \mathrm{jam}$ ).

Reaksi oksidasi pada suhu $50^{\circ} \mathrm{C}$ menyebabkan terjadinya kenaikkan swelling power pati sukun termodifikasi dari $2,3 \mathrm{~g} / \mathrm{g}$ menjadi $3,67 \mathrm{~g} / \mathrm{g}$ dan nilai water solubility dari $0,95 \%$ menjadi $2.69 \%$. Zhang dkk. (2012) melaporkan bahwa peningkatan suhu reaksi oksidasi dapat meningkatkan aktivitas radikal hidroksil sehingga struktur kristalin dari amilosa dapat dipecahkan dan amilopektin dapat mengabsorpsi air dari sistem sehingga meningkatkan swelling power pati termodifikasi. Pati teroksidasi pada umumnya mempunyai daya mekar oleh panas (baking expansion) yang lebih besar daripada pati asalnya, dan hal ini tergantung pada kadar amilopektin di dalamnya (Takizawa dkk., 2004). Selain itu, pati teroksidasi lebih mudah larut dalam air dan mempunyai pasta yang jernih/transparan (Takizawa dkk., 2004).

Menurut Zhang dkk. (2012) peningkatan suhu reaksi oksidasi akan meningkatkan aktivasi hidrogen perosida dan pembengkakan butir pati, tetapi jika suhu diatas $55^{\circ} \mathrm{C}$ dapat terjadi peruraian oksidator dan menurunkan nilai derajat oksidasinya (DO).

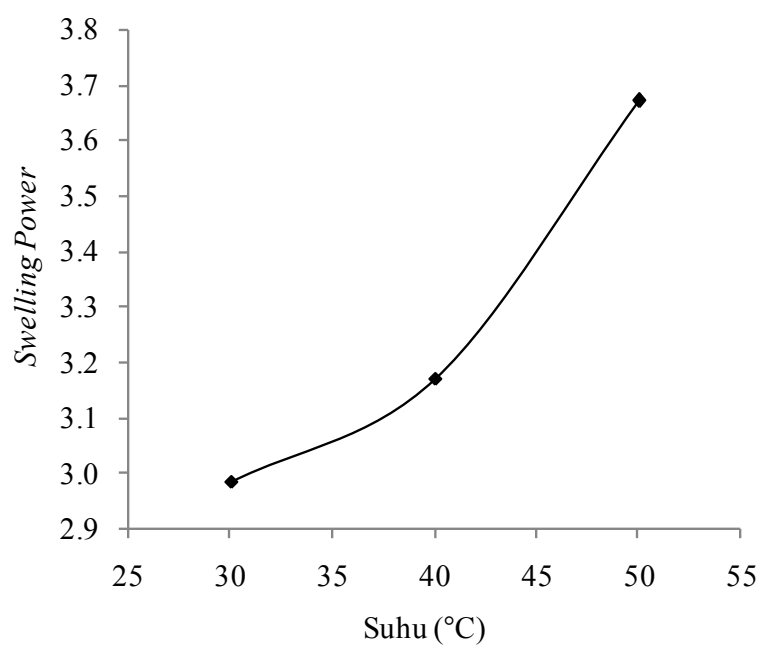

Gambar 5. Pengaruh suhu oksidasi terhadap swelling power pati sukun termodifikasi dengan konsistensi luluhan $20 \%$, konsentrasi $\mathrm{H}_{2} \mathrm{O}_{2} 2 \%$ dan waktu reaksi 30 menit

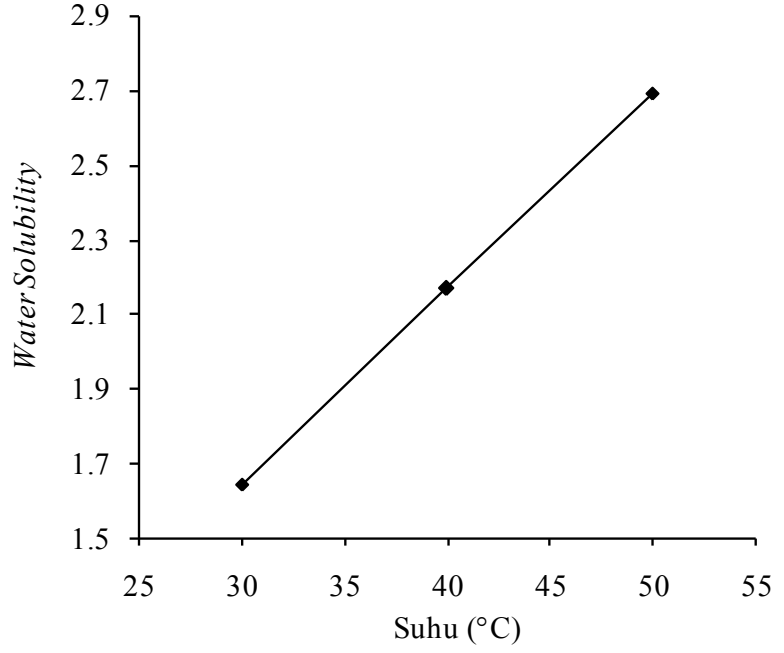

Gambar 6. Pengaruh suhu oksidasi terhadap water solubility pati sukun termodifikasi dengan konsistensi luluhan $20 \%$, konsentrasi $\mathrm{H}_{2} \mathrm{O}_{2} 2 \%$ dan waktu reaksi 30 menit

\subsection{Analisis Struktur Mikro Pati Sukun}

Hasil pemindaian dengan mikroskop elektron pada pati sukun sebelum dan sesudah proses oksidasi dengan larutan hidrogen peroksida ditampilkan pada Gambar 7. Loos dkk. (1981) melaporkan bahwa pati sukun berbentuk bola dengan ukuran 10-20 $\mu \mathrm{m}$ dan terdiri dari segmen-segmen yang berbentuk heksagonal. Sedangkan ukuran butir pati sukun pada penelitian ini lebih kecil, yaitu berkisar antara 3-8 $\mu \mathrm{m}$. Permukaan butir pati sukun nampak halus dan tidak ada celah atau retakan. Hasil kajian ini sejalan dengan hasil penelitian sebelumnya yang dilakukan oleh Loos dkk. (1981) untuk sukun yang berasal dari Puerto Rico (Gambar 8).

Pada Gambar 7 tidak nampak adanya perbedaan yang nyata antara morfologi dan struktur butir pati sukun sebelum dan sesudah oksidasi dengan larutan hidrogen hidroksida dengan kadar 1-3\%. Hasil serupa juga dilaporkan oleh Sandhu dkk. (2008) dan Kuakpetoon dan Wang (2001) yang tidak menemukan perubahan yang signifikan pada pati kentang, jagung dan beras setelah dioksidasi dengan larutan natrium hipokhlorit $1 \%$ atau setara dengan khlorin aktif $2 \%$. Bahkan, Rutenberg dan Solarek (1984) juga melaporkan hal yang sama untuk oksidasi pati jagung dan kentang dengan larutan natrium hipokhlorit yang mengandung $6 \%$ khlorin aktif. Akan tetapi, jika pati sukun teroksidasi diamati dengan lebih teliti ternyata ada sedikit perubahan pada permukaan butirnya. Hal ini memunjukkan bahwa oksidasi pada pati sukun berlangsung dimulai dari bagian permukaan terluar pada butir pati, kemudian dilanjutkan menuju ke bagian dalam butir pati. Hal ini sesuai dengan fenomena yang dijumpai Kachkarova-Sorokina dkk. (2004) pada 
Teknik, 37 (1), 2016, 38

oksidasi pati dengan larutan hidrogen peroksida menggunakan katalis FePcS.
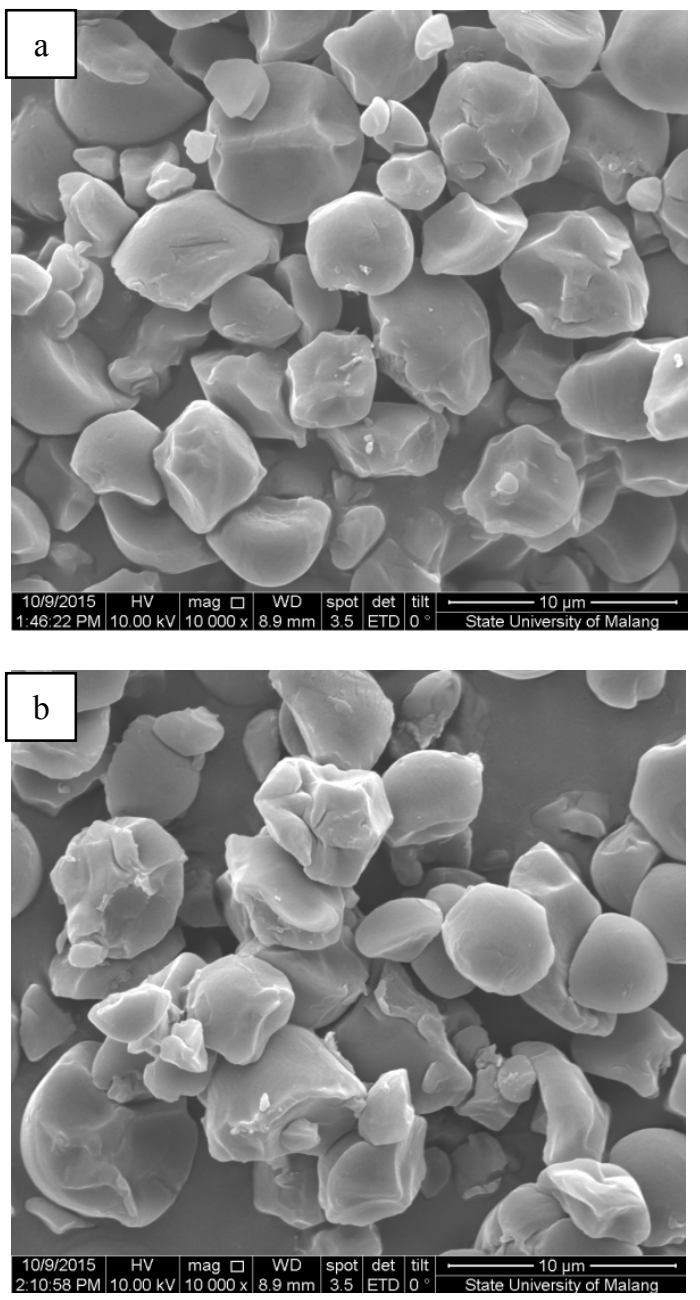

Gambar 7. Struktur mikro pati sukun sebelum (a) dan sesudah (b) oksidasi dengan larutan hidrogen peroksida tanpa katalis

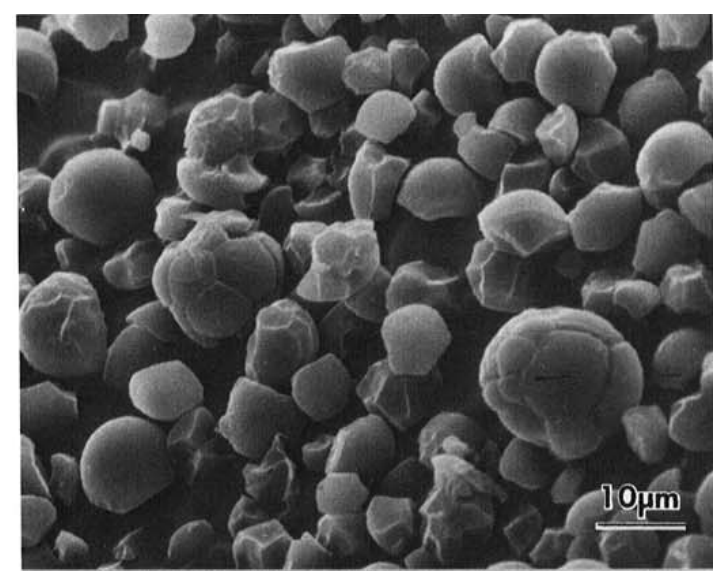

Gambar 8. Struktur mikro pati sukun dari Puerto Rico yang dilaporkan oleh Loos dkk. (1981)

\section{Kesimpulan}

Reaksi oksidasi pati sukun dengan oksidator $\mathrm{H}_{2} \mathrm{O}_{2}$ dan pati hasil oksidasinya dipengaruhi oleh konsistensi luluhan pati, konsentrasi $\mathrm{H}_{2} \mathrm{O}_{2}$, dan suhu reaksi. Pengaruh konsistensi luluhan pati sukun berkaitan dengan ketersediaan radikal hidroksil dalam sistem reaksi dan dibatasi oleh kebutuhan energi yang digunakan untuk mengaduk. Konsentrasi $\mathrm{H}_{2} \mathrm{O}_{2}$ mempengaruhi reaksi oksidasi terkait dengan ketersediaan radikal hidroksil dalam sistem reaksi dan kemungkinan reaksi lanjutan. Seentara itu, suhu reaksi dibatasi oleh suhu gelatinisasi pati sukun dan laju dekomposisi $\mathrm{H}_{2} \mathrm{O}_{2}$ dan sangat mempengaruhi reaksi oksidasi dan hasil pati sukun termodifikasinya. Oksidasi pati sukun pada konsistensi luluhan $20 \%$, konsentrasi $\mathrm{H}_{2} \mathrm{O}_{2}$ sebesar $2 \%$, dan suhu $50^{\circ} \mathrm{C}$ mampu menghasilkan nilai swelling power dan water solubility yang terbaik. Setelah reaksi oksidasi, tidak terjadi perubahan struktur dan morfologi pati sukun teroksidasi secara signifikan.

\section{Ucapan Terima Kasih}

Ucapan terima kasih disampaikan kepada Jurusan Teknik Kimia Fakultas Teknik Universitas Diponegoro yang telah membiayai penelitian ini melalui Surat Perjanjian No. 3821/UN7.3.3/PG/2015 tanggal 7 April 2015. Ucapan terima kasih juga disampaikan kepada Vicky Kartika Firdaus dan Taufik Nuraziz yang telah membantu pelaksanaan penelitian ini.

\section{Daftar Pustaka}

Adebowale, K. O., Olu-Owolabi, B. I., Olawumia, E. K. \& Lawal, O. S. (2005). Functional Properties of Native, Physically and Chemically Modified Breadfruit (Artocarpus artilis) Starch. Industrial Crops and Products, 21, 343-351.

Akanbi, T.O., Nazamid, S., Adebowale, A.A., Farooq, A. \& Olaoye, A.O. (2011). Breadfruit StarchWheat Flour Noodles: Preparation, Proximate Compositions and Culinary Properties. International Food Research Journal, 18, 12831287.

Blazek, J. \& Copeland, L. (2008). Pasting and Swelling Properties of Wheat Flour and Starch in Relation to Amylose Content. Carbohydrate Polymers, 71, 380-387.

Budiyati, C. S. \& Ariyanti, D. (2014). Taro Tube Flour Modification via Hydrogen Peroxide Oxidation. International Journal of Science and Engineering, 7(2), 137-142.

Chung, S. Y., Han, S. H., Lee, S. W., \& Rhee, C. (2010). Physicochemical and Bread-making Properties of Air Flow Pulverized Wheat and Corn Flours. Food Science and Biotechnology, 19(6), 1529-1535. 
Teknik, 37 (1), 2016, 39

Esuoso, K.O. \& Bamiro, F.O. (1995). Studies of the Baking Properties of Non Wheat Flours I. Breadfruit (Artocarpus artilis). International Journal of Food Sciences and Nutrition, 46, 267273.

Gunathilake, K. D. P. P. \& Abeyrathne, Y. M . R. K. (2008). Incorporation of Coconut Flour Into Wheat Flour Noodles And Evaluation of Its Rheological, Nutritional And Sensory Characteristics. Journal of Food Processing and Preservation, 32,133-142.

Hodge, J. E., \& Osman, E. M. (1996). Carbohydrates. In O. R. Fennema (Ed.), Food chemistry (p. 47). New York: Marcel Dekker.

Kachkarova-Sorokina, S. L.; Gallezot, P.; Sorokin, A. B., 2004, A Novel clean catalytic method for waste-free modification of polysaccharides by oxidation, Chemical Communications, 28442845 .

Kainuma, K., Odat, T., \& Cuzuki, S. (1967). Study of Starch Phosphates Monoesters. Journal of Technology Society Starch, 14, 24 - 28.

Kuakpetoon, D. \& Wang, Y. J. (2001). Characterization of Different Starches Oxidized by Hypochlorite. Starch/Stärke, 53, 211-218.

Kuakptoon, D. \& Wang Y. J. (2008). Locations of hypochlorite oxidation in corn starches varying in amylose content. Carbohydrate Research, 343, 90-100.

Kumoro, A. C., Retnowati, D. S., and Budiyati, C. S. (2012). Water Solubility, Swelling and Gelatinization Properties of Raw and Ginger Oil Modified Gadung (Dioscorea hispida Dennst) Flour. Research Journal of Applied Sciences Engineering and Technology, 4(17), 2854-2860.

Kurakake, M., Akiyama, Y., Hagiwara, H., \& Komaki, T. (2009). Effects of Cross-linking and Low Molecular Amylose on Pasting Characteristics of Waxy Corn Starch. Food Chemistry, 116(1), 6670 .

Lawal, O. S. (2004). Composition, Physicochemical Properties and Retrogradation Characteristics of Native, Oxidized, Acetylated and Acid-thinned New Cocoyam (Xanthosoma sagittifolium) Starch. Food Chemistry, 87, 205-218.

Leach, H. W., Mc Cowen, L. D., \& Schoch, T. J. (1959). Structure of the Starch Granules. In: Swelling and Solubility Patterns of Various Starches. Cereal Chemistry, 36, $534-544$.

Loos, P.J., Hood, L. F. \& Graham, H. D. (1981). Isolation and Characterization of Starch from Breadfruit. Cereal Chemistry, 58 (4), 282-286.

Matsuguma, L. S., Lacerda, L. G., Schnitzler, E., Filho, M .A. D. S. C., Franco, C. M. L. \& Demiate, I. M. (2009). Characterization of native and oxidized starches of two varieties of Peruvian carrot (Arracacia xanthorrhiza, B.) from two production areas of Paraná state, Brazil. Brazilian Archives of Biology and Technology, 52 (3), 701713.

Parovuori, P., Hamunen, A., Forssell, P., Autio, K., \& Poutanen, K. (1995). Oxidation of Potato Starch by Hydrogen Peroxide. Starch/Stärke, 47 (1),1923.

Rutenberg, M. W., \& Solarek, D. (1984). Starch Derivatives: Production and Uses. In: Starch: Chemistry and Technology (R. L. Whistler, J. N. BeMiller, \& E. F. Paschall (Eds.), Academic Press, New York.

Sandhu, K. S., Kaur, M., Singh, N. \& Lim, S. T. (2008). A Comparison of Native and Oxidized Normal and Waxy Corn Starches: Physicochemical, Thermal, Morphological and Pasting Properties. LWT - Food Science and Technology, 41, 10001010.

Serrero, A., Trombotto, S., Cassagnau, P., Bayon, Y., Gravagna, P., \& Montanari, S. (2010). Polysaccharide Gels Based on Chitosan and Modified Starch: Structural Characterization and Linear Viscoelastic Behavior. Biomacromolecules, 11(6), 1534-1543.

Silva, R., Ferreira, G., Shirai, M., Haas, Scherer, M., \& Franco, C. (2008). Physicochemical Characteristics of Starches Modified with Potassium Permanganate/Lactic Acid and Sodium Hypochlorite/Lactic Acid. Cïência $e$ Tecnologia deAlimentos, 28, 66-77.

Takizawa, F.F., da Silva, G.D. O., Fran Konkel, F. E. \& Demiate, I. M. (2004). Characterization of Tropical Starches Modified with Potassium Permanganate and Lactic Acid. Brazillian Archives of Biology and Technology, 47(6), 921931.

Tester, R. F., \& Morrison, W. R. (1990). Swelling and Gelatinization of Cereal Starches I. Effects of Amylopectin, Amylose and Lipids. Cereal Chemistry, 67, 551-557.

Tolvanen, P., Sorokin, A., Mäki-Arvela, P., Murzin, D.Y., \& Salmi, T. (2013). Oxidation of Starch by $\mathrm{H}_{2} \mathrm{O}_{2}$ in the Presence of Iron Tetrasulfophthalocyanine Catalyst: The Effect of Catalyst Concentration, $\mathrm{pH}$, Solid-Liquid Ratio, and Origin of Starch. Industrial \& Engineering Chemistry Research, 52, 9351-9358.

Tomasik, P. (2004). Chemical Modifications of Polysaccharides, In: Chemical and Functional Properties of Food Saccharides (Tomasik P., Ed.), CRC Press Inc., Boca Raton.

Varma, A. J., Kokane, S. P., Pathak, G., \& Pradhan, S. D. (1997). Thermal Behavior of galactomannan guar gum and its periodate oxidation products. Carbohydrate Polymers, 32, 111-114 
Teknik, 37 (1), 2016, 40

Wang, Y. J. \& Wang, L. (2003). Physicochemical properties of common and waxy corn starch oxidized by different level of sodium hypochlorite.Carbohydrate Polymers, 52, $207-$ 217.

Zdanowicz, M., Schmidt, B., \& Spychaj, T. (2010). Starch Graft Copolymers as Superabsorbents Obtained Via Reactive Extrusion Processing. Polish Journal of Chemical Technology, 12(2), 14-17.
Zhang, Y. R., Wang, X. L., Zhao, G. M. \& Wang, Y. Z. (2012). Preparation and Properties of Oxidized Starch with High Degree of Oxidation. Carbohydrate Polymers, 87, 2554- 2562. 